
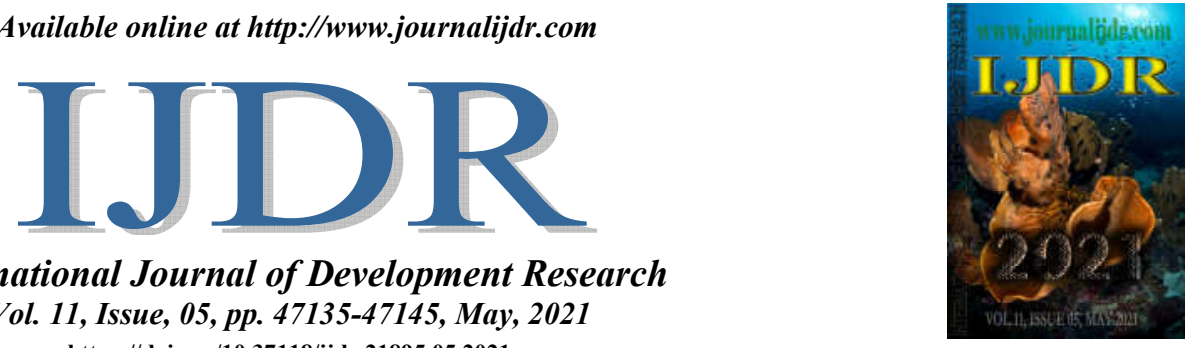

ISSN: 2230-9926

International Journal of Development Research

Vol. 11, Issue, 05, pp. 47135-47145, May, 2021

https://doi.org/10.37118/ijdr.21895.05.2021

\title{
THE JUDGMENT OF CRIMES AGAINST HUMANITY IN BRAZIL: ANALYSIS THROUGH THE CRITICAL CRIMINOLOGICAL LENS OF LOLA ANIYAR
}

\author{
${ }^{* 1}$ Airto Chaves Junior, ${ }^{2}$ Bruno Amaral Machado and ${ }^{3}$ Thiago Aguiar de Pádua \\ 1Professor at the Strict Sensu Postgraduate Law program (UNIVALI LL.M. and PhD Law Program) \\ ${ }^{2}$ Post-doctorate in Sociology From the University of Brasília \\ ${ }^{3}$ Professor at the Strict Sensu Postgraduate law program (UDF LL.M. Law Program)
}

\section{ARTICLE INFO}

\section{Article History:}

Received $19^{\text {th }}$ February, 2021

Received in revised form

$03^{\text {rd }}$ March, 2021

Accepted $11^{\text {th }}$ April, 2021

Published online $30^{\text {th }}$ May, 2021

\section{Key Words:}

Criminal Control in the Dictatorship;

Brazilian Supreme Court; ADPF 153;

Amnesty; Extradition 1362; Lesa-humanity.

\begin{abstract}
In this article we discuss two recent Brazilian Supreme Court judgments about crimes committed during the civil-military dictatorship: Allegation of Disobedience of Fundamental Precept suit $\mathrm{n}$. 153 (constitutionality of the 1979 amnesty law), and Extradition suit n. 1362, that discussed the extradition of an Argentine citizen who was convicted of committing crimes against humanity during the Argentine dictatorship). We analyze the role of the Brazilian Supreme Court in the (re) construction of the "criminal problem" and "criminal control" in relation to crimes against humanity perpetrated during the periods of the Argentine (1978-1983) and Brazilian (1964-1985) dictatorship. We take Lola Aniyar de Castro Thought's, seeking some inspiration, for whom the criminology of the 21 st Century is the "criminology of human rights", and criminal control would be the thermometer of human rights. In the last part of this article, we discussed what seems to have been "the triumph of Lewis Carroll", in the metaphor of reversing meanings: when protecting human rights is not to protect human rights, by creating an ad hoc decision-making rule from which "remembering is to forget", and "forgetting is to remember", provided that, from the peculiar Rule n. 42, the investigation and accountability for crimes against humanity are not allowed.
\end{abstract}

Copyright (C) 2021, Airto Chaves Junior et al. This is an open access article distributed under the Creative Commons Attribution License, which permits unrestricted use, distribution, and reproduction in any medium, provided the original work is properly cited.

Citation: Airto Chaves Junior, Bruno Amaral Machado and Thiago Aguiar de Pádua, 2021. "The judgment of crimes against humanity in brazil: analysis through the critical criminological lens of lola aniyar", International Journal of Development Research, 11, (05), 47135-47145.

\section{INTRODUCTION}

"Hello darkness, my old friend, I've come to talk with you again, Because a vision softly creeping, Left its seeds while I was sleeping, And the vision that was planted in my brain Still remains, Within the sound of silence. (...) People talking without speaking, People hearing without listening". ${ }^{\prime}$

"The sounds of silence", music authored by Simon and Garkunfel, narrates one's appeal to the darkness, treating it as an old friend, telling it that people hear, but do not listen. The new interpretation of the song by the group Disturbed remains current, touching and melancholic. Talking to tired auditoriums, invented (or imaginary) can bring about the same sensation. Thiago de Mello, Amazonian writer, despiteand because of darkness, poetically announced that is necessary to keep on singing; a sublime vision that gains color when

This text is part of the production by the StrictoSensuPos-Graduate Law Program at UDF, UNIVALI and UniCEUB.

${ }^{1}$ See SIMON, Paul; GARFUNKEL, Art. The Sounds of Silence. Sounds of Silence. Washington: Columbia, 1965. juxtaposed to the 13 articles (and plus the final one) of his "Statute of Men" (as a Permanent Institutional Act), in which the use of the word "freedom" is prohibited, that it should be suppressed from the dictionaries (and from the misleading marsh of mouths). It should become something "live and transparent", as if in a fire or a river, and whose living should (always) be in the hearts of men. By denouncing the limitation of normativity ${ }^{2}$ as conditioners and limiters of conduct (but also as a response to the permissive normativity to the massive violation of human rights), he said, in the darkness, it was decreed that nothing should be obligatory (nor forbidden); that everything should be permitted, even - and inclusive - playing with the rhinos and walking in the afternoon with an immense begonia in the lapel. And that, by irrevocable decree, the kingdom of permanent justice and clarity was to be stablished, in which joy should be a generous flag, forever unfurled in people's soul.

\footnotetext{
${ }^{2}$ See recent interview with the poet, by occasion of his 90 years. DE MELLO, Thiago Entrevista: Autor de 'Faz Escuro Mas Eu Canto', Thiago de Mello comemora 90 anos em São Paulo. Estadão. Caderno Cultura, de 15 de março de 2016. Disponível em $<$ http://cultura.estadao.com.br/noticias/literatura,autor-de-faz-escuro-mas-eu-canto-thiago-de-mello-comemora-90-anos-em-sao-paulo,10000021236>, acesso em 21.10.2020. Confira-se, ainda: DE MELLO, Thiago. Faz Escuro, mas eu canto. $21^{\mathrm{a}} \mathrm{Ed}$ São Paulo: Bertrand Brasil, 2003.
} 
The debate about the potential of art in juridical hermeneutics has awakened the interest of researchers in this area. So, as in social sciences (sociology, criminology, anthropology, psychoanalysis, political science), literature, music and film propitiate an arsenal of semantic artifacts to rethink the theory and the practice of law ${ }^{3}$. In this essay, the poetry and the music reminds us of the appeal of Lola Anivar de Castro (henceforth just Lola), Venezuelan criminologist, deceased in 2016; of Lewis Carroll literature, alerting us about the dangerous triumph in the "criminological view": it was strange to run so much to go to "the other side", when in, Wonderland, you run to stay in the same place. And that to know the sum of a simple operation $(2+2)$, it would be necessary to ask "who bosses" $"$. The meaning inversion, abundant in Carroll's literature, make us think in a deafening silence, that continues to sound, from Lola's first unburdening, the triumph of juridical rhetoric that "approves" the massive violation of human rights. The reflection take us to an initial questioning, the conductive wire of our text: are the human rights not vulnerable by the validation of juridicalAmnesty Laws or by theacknowledgement of the prescritbility of crimes against humanity (cases in Brazil from the decisions of the Brazilian Supreme Court, respectively, the judgments of the ADPF n. 153, and the Extradition n. 1362)?

As a narrative, we do not (re)present "the truth", but the "possibilities" or "alternative readings", as observed by Lola when she responded Rose Del Omo in "America y sucriminologia". A story can only be a simple narrative of events, a relation of documents, dates, lists, books, names (...) what was once called "the dead weight of history". But it can also be one interpretation in tune with a selected paradigm to understand society. Often, they are paths that interpenetrate, with the presence of the always possible risk, not always calculated, of partiality, both in evaluation about the selection of documents, from epistemological to personal guidelines, and in limitation of the hermeneutic formulas that lead to desired arrangements ${ }^{5}$. The two "truths" of Lewis Carroll seem immutable to Lola's eyes considering the experience of Latin-American countries with the factors of power and "criminal problems" in dictatorial regimes. In honor of the critical legacy of the Venezuelan thinker and this important provocative fragment, let us resume Lewis Carroll's others two truths. It is worth remembering the highlight given to Brazil in the 23rd International Course on Criminology held in Maracaibo, Venezuela ${ }^{6}$, inaugust 1974 . When our representatives, those present at the event, opted to talk about the traffic delicts, ina moment which echoed the political violence in the country, we preferred to run and stayed in the same place while, at the same time, we gave the impression of having inquiredwho bossed to know how much was the result of the sum $2+2$.

After 40 years, because of the deafening "silence", we resume the reflection with a similar end: to say that the writing of Lewis Carroll remains current and instigating. A sort of "contingency herald of the human rights". Our writing inspires in a metaphor contained in "rule n. 42" of Wonderland and, yet, ina fragment of the "Snark Hunt", to think on an appeal to truth by repetition. In the narrative, when a" thing"is repeated thrice, it means it must be true, in a "self-fertilizing" process, which evokes the character of captain Bellman in "The

${ }^{3}$ The Art constitutes in an important spring of signifiers to other areas, as in social sciences. About law and literature see POSNER, Richard A. Remarks on Law and Literature. Loyola University Law Journal, 23, p. 181-195, 1991-1992. Sobre direito e literatura no Brasil, ver TRINDADE, André Karam; GUBERT, Roberta Magalhães; COPETTI NETO, Alfredo. Direito \& Literatura: Discurso, Imaginário e Normatividade. Porto Alegre: Nuria Fabris, 2010. Sobre as interconexões entre cinema e criminologia, ver MACHADO, Bruno Amaral; ZACKSESKI, Cristina; PIZA, Evandro C. Cinema e Criminologia: narrativas sobre a violência. São Paulo: Marcial Pons, 2016. Sobre arte e psicanálise, ver RIVERA, Tânia. Arte e psicanálise. Rio de Janeiro: Jorge Zahar, 2002. Em relação ao tema, sob a perspectiva sistêmica, conferir BEEBEE, Thomas. Can Lawand-Humanities survive Systems Theory? Law \& Literature, n. 244, 2010.

${ }^{4}$ SeeDE CASTRO, Lola Aniyar. O triunfo de Lewis Carroll. A nova criminologia latinoamericana. Discursos sediciosos: crime, direito e sociedade. Rio de Janeiro: Freitas Bastos, 2000, p. 137

${ }^{5}$ SeeDE CASTRO, Lola Aniyar. Criminologia da Libertação. Rio de Janeiro: Revan, 2005 , at 19.

${ }^{6}$ SeeDE CASTRO, Lola Aniyar. Criminologia da Libertação. Rio de Janeiro: Revan, 2005 , at $24-25$.
Hunting of the Snark", which describes "an impossible trip, of an improbable crew, in search of an inconceivable creature". In the case of the judgment of the "pie theft", in relation to Alice's testimony, a singular scene surges from Carroll's plume, when the rules were created to favor or disadvantage certain people, in given circumstance. The fragment refers, implicitly, to the "complaint" of selectivity of the penal control agencies. The rule ${ }^{9}$ n. 42 , materializes very well the metaphor of the "criminal problem" and of the "criminal control", and the articulation between both, central to rethink the contribution of Lola to analyze our marginal realities ${ }^{10}$. The inspiration in Lola's legacy reveals itself useful to reflect about differentmanifestations of the criminal control. In this case study, we have used two decisions of the Brazilian Supreme Court.

We suggest that the FSC of Brazil, when confronted with a possible moment of reckoning with the past, whenasessing the constitutionality of the Amnesty Law ${ }^{11}$, inApril 2010, ruled the ADPF 153, and, when evaluating the imprescriptibilityof the crimes against humanity (Extradition 1362), opted not only to "run to stay in the same place", inquiring the legislator of the dictatorial regime how much was the sum of the moment, but also - as it seems evidentopted to repeat the story that, only by repetition, pretended it had become true, creating, with this, its own "rule n. 42". To descant about the treatment the courts concede to oblivion (whether in the relative notion of amnesty or prescription), can lead us to talk about it (oblivion) from different theoretical and imagetic arrangements, whether the oblivion as antipode to remembrance (!?), to the oblivion as punishment (!?), to the oblivion as a limit and protection. But it will always be inevitable in the pictures and images that certain annoying questions will arise: Remember (forget) what? Why? Whom? What for? Our proposal is to discuss the Brazilian Supreme Court conceptions of penal control ${ }^{12}$, from Lola's criminological critical thought, in two judgements whose object were the acts

\footnotetext{
Fragment of the "Hunt" described in genuine "non sense" by Lewis Carroll: "Just the place for a Snark!" the Bellman cried, / As he landed his crew with care;/ Supporting each man on the top of the tied/ By a finger entwined in his hair./ "Just the place for a Snark! have said it twice:/ That alone should encourage the crew. / Just the place for a Snark! I have said it thrice:/ What I tell you three times is true." Cfr. CARROLL, Lewis. The Hunting of the Snark. Lightning Source, 2007.

${ }^{8}$ See WILLIAMS, Sidney; MADAN, Falconer. Handbook of the Literature of the Rev. C. L. Dodgson,citadosen Martin Gardner: The Annotated Snark, Penguin Books, 1974

${ }^{9}$ Fragment of "rule n. 42", invented by the judge in the explicit complaint of Lewis Carroll“ (...) As soon as the jury had a little recovered from the shock of being upset, an their slates and pencils had been found out and handed back to them, they set to work very diligently to write out a history of the accident, all except the Lizard, who seemed to much overcome to do anything but sit with its mouth open, gazing up into the roof of the court. "What do you know about this business?" the king said to Alice. "Nothing," said Alice. "Nothing whatever?" persisted the King. "Nothing whatever," said Alice. "That's very important," the King said, turning to the jury. They were just beginning to write down on their slates, when the White Rabbit interrupted: "Unimportant, your majesty means, of course", he said in a very respectful tone, but frowning and making faces at him as he spoke. "Unimportant, of course, I mean," the king hastily said, and went on to himself in an undertone, "important - unimportant - unimportant - important ---"as if he were trying word sounded the best. Some of the jury wrote it down "important," and some "unimportant." Alice could see this, as she was near enough to look over their slates; "but it doesn't matter a bit,", she thought to herself. At this moment, the King, who had been for some time busily writing in his note-book, called out "Silence!" and read out from his book "Rule Forty-two. All persons more than a mile high to leave the court." Everybody looked at Alice. "I'm not a mile high," said Alice. "You are," said the King. "Nearly two miles high," added the Queen. "Well, I shan't go, at any rate," said Alice; "besides, that's not a regular rule: you invented it just now." "It's the oldest rule in the book," said the King. "Then it ought to be Number One," said Alice. The King turned pale, and shut his book hastily. (...)". Cfr. CARROLL, Lewis. Alice's Adventures in Wonderland, with forty-two illustrations by John Tenniel. D. Appleton and CO: 1866, at 178-180.

${ }^{10}$ See DE CASTRO, Lola Aniyar. Criminologia da Libertação. Rio de Janeiro: Revan, 2005 , at 237 e ss.

${ }^{11}$ Subsequently (in 2014), the judicial process (ADPF $n^{\circ} 320$ ) was filed before the same Brazilian Supreme Court, in which it was postulated that the Amnesty Law (Federal Statute n. 6.683/1979), was not applied "to crimes of serious violations of rights human rights committed by public agents, military or civilians ", due to the decision issued by the Inter-American Court of Human Rights, in the case of Gomes Lund.But the answer can be the same, in a race where you stay in the same place.

${ }^{12}$ About conceptual origins of the social control, the distinction with the political and penal control, as well as the typologies (formal and informal control), see: MELLOSSI, Dari. El estado del control social. Umstudio sociológico de los conceptos de estado y de control social en la conformación de la democracia. México, Siglo XXI, 1992. It is worth checking the critic to the usage, not always adequate, made to the penalists, the concept of social control, see: BERGALLI, Robert et al. Control Social Punitivo. Sistema penal instancias de aplicación (Policía, Jurisdicción y Cárcel). Barcelona: Editorial María Jesús Bosch, S.L., 1996.
} 
practiced during the Brazilian (1964-1985) and Argentinian (19761983) period.

\section{Fragments of the latin-maerican criminolgical thought: interpretation vectors for a criminal rereading of the crimes against humanity}

In the late $60 \mathrm{~s}$, critics of the criminological movements, started in Europe and in the United States, promoted a radical critic to the etiological criminology (biocriminology and criminal sociology), whose object has historically been the causes of crimes. This rereading, oriented through a Marxist lens, lead to the reconfiguration of the social reaction paradigm, now turned to the structures, especially economical, that mold the social defense ideology, justify penal law and criminological thoughts that traditionally justify the exercise of the punitive power ${ }^{13}$. The critical movement in LatinAmerica, impelled by the Congress held in Venezuela, in 1974, captained by Lola and Rosa de Olmo, constituted a historical mark in the Latin-American critical agenda, by redirecting the focus to an institutional violence exercised by the elites. ${ }^{14}$ The multidisciplinary approach, articulated the political and social transformation project, attended by representatives from Colombia, Brazil, Chile, Venezuela and Brazil (amongst other countries) and dedicated to debate roots of the great social and economic inequalities in the countries of the region and, especially, to denounce the violence of the State, in the form of criminal practices such as torture, forced vanishings and death. experienced by marginal societies ${ }^{16}$. The diversity of criminological thoughts, the configuration different research and object fields, have been awakening the attention of specialists for many years. In a recent research we sustained that the crimologies can be described as concurrent scientific subsystems. The paradigms are not successive, they are on constant adaptation, with new theoretical and methodological paradigms ${ }^{17}$. In this article, we would rather resume the analytical modes proposed by the Venezuelan criminologist, inspirational to think in a theoretical matrix to reflect about the crimes against humanity. The criminologies, as pluralistic classified in the taxonomy proposed by Lola ${ }^{18}$, preoccupies - each one of them - with specific objects of study: the classic criminology (delict), the positivist criminology (delinquent), and organizational criminology (delinquency), the interactionist criminology (social reaction), and, the radical criminology or critic of the Human Rights (social control), with quite remarkable attributes and descriptions:

In the model proposed by Lola $^{19}$, there is a logical sequence of analysis of the called "criminal matter", which refers to the "social control" as a starting point. In its conception, the social control would be a defining instrument of the concepts of delict, delinquent, delinquency, primordial to the "criminalization process", which are selective and of political nature. The reflection inquires the ideal diffused by the Jurisprudence of Concepts in the XIX century. In the "Heaven for Legal Concepts" by Jhering ${ }^{20}$, full of caricature expressions, certainly there would be a "producing machine of delicts and delinquents", beyond the already known "tallow stick of juridical

\begin{tabular}{|l|l|l|l|l|l|}
\hline Classic & Positivist & Organizational & Interactionist & $\begin{array}{l}\text { Radical Critic and } \\
\text { of Liberation }\end{array}$ & Of the Human Rights \\
\hline Speculative, legal. & $\begin{array}{l}\text { lassic } \\
\text { Criminology, } \\
\text { criminal sociology, } \\
\text { sociology of } \\
\text { deviance conducts }\end{array}$ & $\begin{array}{l}\text { Criminal Justice, Systemic } \\
\text { Criminology }\end{array}$ & Social Reactions & Power and interests & $\begin{array}{l}\text { Emancipators } \\
\text { generalizable interests. }\end{array}$ \\
\hline $\begin{array}{l}\text { Non-retroactivity, legal } \\
\text { reserve, codification, } \\
\text { disciplined } \\
\text { interpretation, } \\
\text { proportionality. }\end{array}$ & $\begin{array}{l}\text { Focus on "causes" } \\
\text { of actions in } \\
\text { delicts }\end{array}$ & Criminal Politics. & $\begin{array}{l}\text { Labelling } \\
\text { Approach }\end{array}$ & $\begin{array}{l}\text { Politology of the } \\
\text { normative delict. } \\
\text { Social compromise. }\end{array}$ & $\begin{array}{l}\text { Victim's penal law. } \\
\text { Penal Law. }\end{array}$ \\
$\begin{array}{l}\text { Individual macy; minimal } \\
\text { (individual in } \\
\text { society). }\end{array}$ & $\begin{array}{l}\text { Penal Justice Appliances: } \\
\text { penitentiary criminology, } \\
\text { police, Courts, post- } \\
\text { penitentiary. }\end{array}$ & $\begin{array}{l}\text { Evaluation } \\
\text { Relativity }\end{array}$ & $\begin{array}{l}\text { Search for the } \\
\text { essence behind } \\
\text { appearances }\end{array}$ & $\begin{array}{l}\text { Measures and alternative } \\
\text { penalties to the deprivation of } \\
\text { liberty. Participation. Human } \\
\text { Rights as an object and as a } \\
\text { limit }\end{array}$ \\
\hline $\begin{array}{l}\text { Repression: legal } \\
\text { control. }\end{array}$ & $\begin{array}{l}\text { Reintegration, } \\
\text { society reform. }\end{array}$ & $\begin{array}{l}\text { Efficiency } \\
\text { reintegration. }\end{array}$ & & \\
\hline
\end{tabular}

Throughout the 1980s, one of the most relevant themes in the LatinAmerican criminology critic was the judgement and accountability of the authors of the crimes against humanity, practiced by the dictatorial regimes ${ }^{15}$. One important moment in the critical debate occurred from 1985 onwards. Lola is interpellated and responds an article from NovoaMonreal, who appointed the supposed "confusion" of the Latin-Americans among the fields of scientific research and that of the social fight. Inspired by the romance "El Jardín de el lado", from Donoso, Chilean writer, Lola reaffirms the critical position of engagement in the fight for social transformation and rebuke the accusation, considered distant and alien to the reality

\footnotetext{
${ }^{13}$ See the seminal work of BARATTA, Alessandro.Criminología crítica e crítica do direito penal:Introdução à sociologia do direito penal. $2^{a}$ ed..Trad.: Juarez Cirino dos Santos. Rio de Janeiro: Freitas Bastos, 1999. Conferir extensa referência ao movimento e como foram articuladas as reflexões sobre os novos caminhos para a pesquisa criminológica: VAN SWAANINGEN, René. CriticalCriminology: VisionsfromEurope. London: Sage, 1997, pp. 51-107 e 97-207; LARRAURI, E. La Herencia de la Criminología Crítica. $3^{\text {a }}$ Ed. Madri: Siglo Veintiuno de España Editores, 2000.at 67-75.

${ }_{14}$ Sobre a violência produto do funcionamento regular das instituições, conferir: CHAVES JUNIOR, Airto. Além das Grades: a paralaxe da violência nas prisões brasileiras. Florianópolis/SC: TirantloBlach, 2018.

${ }^{15}$ See BERGALLI, Roberto. Argentina: cueestión militar y discurso jurídico del olvido. Doxa, Cuadernos de Filosofía del Derecho, n. 4, 1987, pp. 381-402. BERGALLI, Roberto. Una sociología del control penal para América Latina: la superación de la criminología. In: BERGALLI, Roberto; BUSTOS RAMÍREZ, Juan (Comp.). El poder penal del Estado. Buenos Aires: Depalma, 1985, p. 3-23For an extensive and detailed analysis of criminological thinking in Latin America, see: ANITUA, Gabriel Ignacio. Historia de los pensamientos criminológicos. Buenos Aires: Del Puerto, 2005, p. 418-426.
}

concepts", the "combing hair machine", the "fiction machine", the "building machine, the "the reconciling contradictory passages machine", the "dialectic drilling machine" and the "wall of vertigo". However, we would not be talking about a "paradise", but very appropriately of a "hell" or a "purgatory", closest to what Robert Ferguson $^{21}$ conceived when he referred to Dante's two first comedy

${ }^{16}$ See NOVA MONREAL, Eduardo. Desorientación epistemológica en la criminología crítica? Revista Doctrina Penal, n. 8, Depalma, Buenos Aires, 1985. Seethe replica of DE CASTRO, Lola Anyiar. El Jardín de al lado. Revista Doctrina Penal, Depalma, n. 8 Buenos Aires, 1985. Andsuccessivepapers: NOVA MONREAL, Eduardo. Lo que hay al lado no es un jardín: mi réplica a Lola Aniyar de Castro, Revista Doctrina Penal, n. 9 Depalma, Buenos Aires, 1986. Conferir réplica de DE CASTRO, Lola Anyiar. Un debate sin punto final. Revista Doctrina Penal, Depalma, n. 11, Buenos Aires, 1988.

${ }^{17}$ Se MACHADO, Bruno Amaral. Discursos criminológicos sobre o crime e o direito penal: comunicação e diferenciação funcional. Revista de Estudos Criminais, ${ }^{\circ} 45$, abriljunho, 2012, p. 77-116.

${ }^{18}$ Se DE CASTRO, Lola Aniyar. Pensamento Criminológico. Da Criminologia Clássica à Criminologia dos Direitos Humanos. Belo Horizonte: Mandamentos, 2004.

${ }^{19}$ SeeDE CASTRO, Lola Aniyar. Criminologia da Libertação. Rio de Janeiro: Revan, 2005 , p. 237 e ss.

${ }^{20}$ Originally published as "ImjuristichenBegriffshimmel. EinPhantastiebild", em: R. VON JHERING. Scherz Und Ernst In Der Jurisprudenz, 1884 by Breitkopf\&Hartel, Leipzig Translated into English by Charlotte L. Levy, como "In The Heaven for Legal Concepts A Fantasy", Temple Law Quarterly, vol. 58, 1985, into italian by F. Vassalli, as "Nelcielodeiconcettigiuridici", at: VON JHERING, R. Serio e facetonellagiurisprudenza, trad. di F. Vassalli, Firenze, 1954; and, into spanish by Tomás A. Banzhaf, como: "En e cielo de losconceptosjurídicos. Una fantasía", em: VON JHERING, R. Bromas y Veras en la jurisprudencia. trad. Tomás A. Banzhaf. Buenos Aires: EJEA, 1974.

${ }^{21}$ See FERGUSON, Robert. Inferno: An Anatomy of American Punishment. New Haven Harvard University Press, 2014. 
books. In other words, for us to think about a "hell or purgatory of juridical concepts", in which certainly the "delict and delinquent producing machine" would occupy prominent place. In Lola's synthesis, inspired by a long tradition of the critical criminological thought, both European and north-American, marked by the reinterpretations of the traditions known as Labelling Approaches under the Marxist focus, we see that the "social control" creates the delicts when it defines them (legislative-wise), as well as it produces the delinquent by labelling, selectively, those deviants who will receive the label (judiciary-constabulary level), besides instituting the official criminality (apparent) when it defines the delict and selects the cases included in the registers of the official organs, operating inlevels of formal penal control (police, courts, prisons, etc.) and nonpenal control (religion, school, family, media, political parties, public opinion, etc.) $)^{22}$.

No criminological focus of critical nature could prescind from primary socialization forms (education), once it institutes the appropriate conditions of consent and legitimacy, observing, yet, the fact that the treatment and repression (reeducation) are substitute socialization forms. Very especially, occupying a prominent place in Lola's research, there is the search for understanding the correlation between media, the economical-political power, and the construction of fear $^{23}$, which leads to the backbone of this article. Such indoctrination apparatus and the production of caricáture of the intern enemy were put in full functioning by the dictatorial regime of 1964, in Brazil, and of 1976, in Argentine. We propose to observe, critically, part of the legacy of both recent dictatorial regimes, as the ones kept in Brazil (1964 - 1985) and in Argentina (1976-1983), that would have followed similar paths in what refers to the construction of the "criminal problem", in the design of a common enemy (through forms of formal and informal control).

\section{Brazilian supreme court and the trial of crimes against humanity: penal control and the large termidor}

The penal control is the "thermometer of the human rights". It constitutes a series of elements of democracies and, in some forms, of all governments that seek to legitimize their ideologies by juridical rhetoric $^{24}$. Lola, in a mature perspective as theoretician and militant, maintains in her writings of the 2000s that the criminology of the XXI century would be the criminology of the human rights ${ }^{25}$. In her proposal, the authors of crimes against humanity should be criminalized and held accountable, mainly in the periods of dictatorship, when massive violations of rights occurred ${ }^{26}$. The writings of the Venezuelan criminologist are inspiring to remember and reflect about the recent history of our region. In this sense, talking about the Brazilian dictatorship (1965-1985) and the Argentine one (1976-1983), of the penal control as a thermometer of the human rights, such as observed by Lola, equals to say that the

\footnotetext{
${ }^{22}$ See CASTRO, Lola Aniyar de. Criminologia da Libertação. Rio de Janeiro: Revan, 2005. at. $237 \mathrm{e}$ ss.

${ }^{23}$ See CASTRO, Lola Aniyar de. Seguridad: Propuestas para una vida sin miedo y sin violencia con respecto a los derechos humanos. Revista Pensamiento Penal, abr. 2007. ${ }^{24}$ In the Southern Cone, countries with different historical traditions such as Brazil, Argentina, Chile and Uruguay, went through similar problems, with different positions of the Courts in the period of democratic transition, in the search for the responsibility of the perpetrators of crimes during the respective dictatorships. See. REQUA, Marny. A Human Rights Triumph? Dictatorship-era Crimes and the Chilean Supreme Court. Human Rights Law Review, v. 12, n. 1, 2012. CORREA S, Jorge. Dealing with Past Human Rights Violations: The Chilean Case After Dictatorship. Notre Dame Law Review, v. 67, 1992; MEZAROBBA, Glenda. Between Reparations, Half Truths And Impunity: The Difficult Break With The Legacy Of The Dictatorship In Brazil. SUR - UR - Int'l J. on Hum Rts. v. 7, n. 13, Dec. 2010; SOITMAN, Daniel. Applauding Uruguay's Quest for Justice: Dictatorship, Amnesty, and Repeal of Uruguay Law no. 15.848. Washington University Global Studies Law Review, v. 12, 2013; GUEMBE, Maria Jose. Reopening of Trials for Crimes Committed by the Argentine Military Dictatorship. SUR Int'l J. on Hum Rts. v. 115, 2005; MIGNONET, Emilio Fermin; ESTLUNDTT, Cynthia L.; ISSACHAROFFTTT, Samuel. Dictatorship on Trial: Prosecution of Human Rights Violations in Argentina. 10 Yale J. Int'l L. v. 118, 1984.

${ }^{25}$ See CASTRO, Lola Aniyar de. La Criminologia Crítica em Siglo XXI como criminologia de los derechos humanos y contra-reforma humanística o las teorias criminológicas no son inocentes. Revista Interferencia - Derechos y seguridade humana,

p. $15,2009$.
${ }^{26}$ See CASTRO, Lola Aniyar de. Pensamento Criminológico. Da Criminologia Clássica à

Criminologia dos Direitos Humanos. Belo Horizonte: Mandamentos, 2004.
}

penal control in these regimes (formal and underground ${ }^{27}$ ) systematically violated the human rights, seeking to legitimize their objectives. Lola's position seems to approach the views ofJoaquín Herrera Flores, for whom the human rights should be situated inside the social reality, conformed by different fields (economical, juridical, and cultural), each of one of them composed of a set of symbolic capitals, institutional, etc., distributed hierarchically and unequally in function of the relations of power and $\operatorname{strength}^{28}$. The tension between these forces - whether in the criminological field or in the constitutional philosophy, when we face institutional rupture, allows us to talk about a "Termidor Lake", as suggested by Gerardo Pisarello $^{29}$, in allusion to the month of the republican calendar instituted by the French Revolution which gave place to the coup d'état of 1794, against the democratic government surged after the fall of the Monarchy and the proclamation of the Republic. The expression alludes, yet today, to the rupture of the democratic experiences. Let us, then, talk about a "Termidorian Criminology", if for any reason, the traditional notions of delict, delinquent, and delinquency are perpetrated (beyond the cycle of the dictatorial regime), in which refers to the "criminal question", tied to the "political and social controls" (formal and informal), gestated during the dictatorial regimes, with the practice of massive violations of human rights that, even after the democratic opening, are observed by organizations of the justice systems as immune acts to the punitive power.

Let us take as an example, by the way, four factual-conceptual elements for the classification of crimes against humanity ${ }^{30}$, that were committed by the Brazilian and Argentine dictatorial regimes, respectively referent to: 1) the active subject; 2) the violating act against human dignity; 3 ) in some cases, the expectative of protection in impunity; and, 4) the social transcendence of the practiced act. About the active subject, there are those acts practiced by agents of the dictatorial State by direct participation, or by indirect form through sympathizers (but with their tolerance), public and explicit or even clandestinely. With regards to the violation of human dignity, it is an action that aims to denigrate one's dignity to achieve a political end, with physical or moral violation. On one side, we observe that the authors of these mentioned acts are institutionally protected by a system of fact or law that permits, favors, or grants their impunity. On the other side, the act transcends the victims, affecting all the community, even in an international context, in grave violation of dignity $^{31}$. In Brazil, we face the vestiges (some of them evident) of this large "Termidor", especially if we observe the institutional rupture occurred in March 1964, realized from a concert between civilians, military, businessmen, media. The Institutional Act (IA)of 1964 created the intern enemy the it sought to fight, expressed in its exposition of reasons. Here is the fragment of the IA n.1: “( ...) fulfill the mission to restore economic and financial order in Brazil and take the urgent measures destined to drain the communist pockets whose purulence had already infiltrated not only the government summit but the administrative dependencies". With the posterior granting of IA $n$. 5 , of 1968, there was recrudescence of the system, with the suspension of the habeas corpus guarantee against political crimes and against the ones committed against national security, as well as the exclusion of appreciation by the juridical power of the acts practiced under its surveillance. National historiography describes murders, tortures, permanent physical and psychological lesions, rapes, violence of gender as a power and domination instrument (crimes against humanity), largely documented in various

${ }^{27}$ On the concept of underground criminal law, see ZAFFARONI, Eugenio Raul. BATISTA, Nilo. SLOKAR, Alejandro. ALAGIA, Alejandro. Direito Penal Brasileiro: Teoria Geral do Direito Penal. Rio de Janeiro: Revan, 2003.

${ }^{28}$ See HERRERA FLORES, Joaquín. La Reinvencion de los derechos humanos. Andalucía: Colecíon Ensayando, 2008. at 83.

${ }^{29}$ See PISARELLO, Gerardo. Un largo Termidor: historia y crítica del constitucionalismo antidemocrático. Quito: Corte Constitucional para el Período de Transición, 2012.

${ }^{30} \mathrm{In}$ this regard, the normative instrument contained in the Convention on the Imprescriptibility of War Crimes and Crimes Against Humanity, adopted by the General Assembly of the United Nations (resolution n. 2391), on November 26, 1968.

${ }^{31}$ See ROJAS, Gerardo Bernales. La Imprescriptibilidad de la Acción Penal en Procesos por Violaciones a los Derechos Humanos. Revista Ius et Praxis, v. 13, n. 1, p. 245 - 265, 2007. 
publications, mainly in the National Truth Committee ${ }^{32}$ and in the research "Brazil Never More" ${ }^{33}$. The laws of the Brazilian dictatorial regime typified crimes, committing penalties (inclusive death and perpetual), enticed the use of the penal apparatus as an instrument to achieve the ends of the dictatorship, the elimination of the chosen enemy. They are exemplified, apropos, with the following normative instruments: Law n. 1802, January 5 1954; the Law-Decree n. 314, March 13 1967; the Law-Decree n. 510, 20 March 1967; the LawDecree n. 898, 29 September 1969, and the law n. 6620, 17 December 1978. The experience was like what occurred in Argentina, where they talk openly about the civil facet of the dictatorship: "Esadimensión civil incluyeaactoreseconómicos, funcionariosciviles (judicialesincluidos), la iglesia, periodistas, medios de comunicación $e$ intelectuales" 34 . Between us, the empirical research that thickens our argument about our "Termidor" lake, projected in 1964, finds in the work of the Hungarian political scientist and historian René Armand Dryfus ${ }^{35}$, written originally in English (State, class and the organic elite: the formation of an entrepreneurial order in Brazil 1961 - 1965), that registered well the civil-military coup d'état, which counted with the support of power structures, including the legislative, executive and judiciary powers. Certainly, there is a necessity of studies that show the distinct institutional specificities and its practices that legitimized exception acts.

Specifically, about the role of the Brazilian Supreme Court ${ }^{36}$, José Afonso da Silva, in his relatively recent work, observed that the Supreme Courted profoundly supported the double dictatorial centralism (federative and organic). The court considered unconstitutional expressions that "roiled the clarity of the constitutional text", data observed in approximately 80 Representations of Unconstitutionality judged by the Republic General-Attorney $^{37}$. The juridical approval that the SFC conceded to the dictatorial regime (1965-1985) reflects in all the power structures, whether when it ceded to the explicit objectives of the coup, that included censorship of the media ${ }^{38}$, or when it juridically validated the radicalization of the fight against the established enemy and its consequences, observable many years later, when it came to judge both the ADPF 153 and the Extradition 1362, that suggests judgment of value about the legitimacy of the dictatorial period, when the Supreme Court was "packed" in a manner like the "court-pakcing plan" of president Roosevelt against the American Supreme Court in the 1930s, during the New Deal ${ }^{39}$.

${ }^{32}$ See BRASIL. Comissão Nacional da Verdade: Relatório. Brasília: CNV, 2014. São três volumes, reunidos em 976 páginas (I), 416 páginas (II), e, 1996 páginas (III).

${ }^{33}$ See BRASIL. Pesquisa Brasil Nunca Mais. São Paulo: Arquidiocese de São Paulo, 1985. There are 12 volumes (Projeto A), composed of 6891 pages, summarized in Project B (book Brazil Nevermore)

${ }^{34}$ See BOHOSLAVSKY, Juan Pablo. ¿Usted también, doctor?: Complicidad de jueces, fiscales y abogados durante la dictadura. Buenos Aires: Siglo Veintiuno Editores, 2015, at 21.

${ }^{35}$ See DREYFUSS, René Armand. 1964: A Conquista do Estado. Ação Política, Poder e Golpe de Classe. Trad. Laboratório de Tradução da Faculdade de Letras da UFMG. 5. ed. Petropolis: editora, 1987.

${ }^{36}$ The referred author cited two (of three) volumes that bring together the Unconstitutionality Representations judged by the Brazilian Supreme Court. See ALBUQUERQUE, Aluísio Xavier de; ABREU, IdunaWeinert de. Representações por Inconstitucionalidade: Dispositivos de Constituições Estaduais. Brasília: Subsecretaria de Edições Técnicas do Senado Federal, 1976; ALBUQUERQUE, Aluísio Xavier de; ABREU, IdunaWeinert de. Representações por Inconstitucionalidade: Dispositivos de Constituições Estaduais. Brasília: Subsecretaria de Edições Técnicas do Senado Federal, 1976; ALBUQUERQUE, Aluísio Xavier de; ABREU, IdunaWeinert de. Representações por Inconstitucionalidade: Dispositivos de Constituições Estaduais (Tomo III - Alagoas a Sergipe). Brasília: Centro de Documentação e Informação Coordenação de Publicações, 1984.

${ }^{37}$ See SILVA, José Afonso da. O Constitucionalismo Brasileiro: Evolução Institucional. São Paulo: Malheiros, 2011. at 151.

${ }^{38}$ In terms of the representativeness of the "institutional engineering" to support the dictatorship, by the way, it should be noted that the legal system allowed the Attorney General to file before the Supreme Court (with exclusivity), Unconstitutionality Representations of law in the face of the Federal Constitution. Such representations were to be judged by the Supreme Federal Court, and their functioning was relatively simple: the interested parties presented a request to the Attorney General of the Republic, who would present the claim before the Supreme Court, under the terms of Federal Law 4337/1964. The Law was silent in the event of the filing of representation by the Attorney General of the Brazilian Republic.

${ }^{39}$ This expression refers to a "political blackmail" that goes back to the 1937 "The Judicial Procedures Reform Bill", often referred to as "court-packing plan", a measure linked to the proposal then President of the United States of America, Franklin D. Roosevelt, who intended to increase the number of Supreme Court judges American Court, since the
The parallel is important ${ }^{40}$. In the Brazilian case, the Constitutional Amendment n. 16, of 1965, instituted the abstract control or norms, which allowed the judgment of law in thesis, in face of the Federal Constitution (without the necessity of a concrete case as a background), a mechanism instituted during the dictatorship, and the IA n. 2, of 1965, that increased from 11 to 16 the number of judges in the Brazilian Supreme Court, all them by direct indication of the President of the Republic. In his interview to the "Oral History of the Brazilian Supreme Court", Rafael Mayer, retired justice from the FSC, remembered his indication to the court in 1978, observing that at that time the Court was counting again with 11 judges, because "in a certain period, the Court, the military government had created 16 vacancies in the Court precisely because it wanted to get rid of certain things" 41 . The "packing" of the Brazilian Supreme Court represented the initial act of alignment with the regime, from the indication of new judges, but the engineering would only be finalized with the posterior retirement of the ministers that apparently did not support the dictatorship postulates, what we can call as "unpacking" of the non-aligned justices. It was the cases of the retirements of EvandroLins e Silva, Vitor Nunes Leal and Hermes Lima, removed from office by the IA n., of 1968, considering yet the "voluntary" retirements of two other ministers, Laffayete de Andrada e Gonçalves de Oliveira ${ }^{42}$, that starred what was depicted as "theater" of resignations ${ }^{43}$, reminding us of previous episodes (in 1863 and $1931)^{44}$ that marked the history of the Court.

In simple arithmetic logic, the presidents of the dictatorship nominated initially 5 judge (with an increase from 11 to 16), and later forced the resignation of 5 judges, when the Court once again counted with 11 members, not forgetting, yet, the retirement of 5 more judges that composed the Court before the increase in the number of vacancies. It is important to observe that all data are important, because hat it not occurred the civil-military coup in 1964, in 1965 general elections would be held, and the eventual president elect would be able to indicate at least 5 judges (in a total of 11) to the Court, what suggests intense dispute to control it. We register, in this sense, the composition of the FSC, from the alteration realized with the granting of the IA n.2, from 1965, the judges indicated by presidents of the dictatorial regime. The presidents of the exception regime nominated 32 judges to the FSC, many of whom stayed in the Supreme Court for long years after the end of the dictatorship, having influenced the jurisprudence even after the advent of a new Constitution, helping to conform to an interpretative model on which the new constitutional device is interpreted in light of - and from the

composition prior to the beginning of the year of his mandate had declared most of his actions unconstitutional policy proposals (New Deal legislation). See FRIEDMAN, Barry. The Will of the people: how public opinion has influenced the Supreme Court and shaped the Constitution. New York: FSG, 2009. at 376.

${ }^{40} \mathrm{In}$ an interview that AliomarBaleeiro, then Associate Justiceof the Brazilian Supreme Court (1965-1975), granted to researcher Osvaldo Trigueiro do Vale, it was clarified that the then military president Castelo Branco knew Roosevelt's "Packing Cout Plan", detailing the arrangement he preferred use in Brazil. See VALE, Osvaldo Trigueiro do. O Supremo Tribunal Federal e a instabilidade politico institucional. 1975. Dissertação (Mestrado). Escola de Administração Pública da FGV, Fundação Getúlio Vargas, Rio de Janeiro, 1975. at. 176

${ }^{41}$ SeeMAYER, Rafael. Entrevista: História Oral do Supremo [1988- 2013]. Rio de Janeiro: Escola de Direito da FGV, 2015. p. 60.

${ }^{42}$ For greater detail about the retirement episodes of the judges in 1968, observe the revealing narrative of EvandroLinds e Silva, one the judges compulsory retired of the FSC. Cfr. LINS E SILVA, Evandro. O Salão dos passos perdidos: Depoimento ao CPDOC. Rio de Janeiro: Nova Fronteira e FGV, 1997, at. 400

${ }^{43}$ We refer to the Reading of exchanged latters, in which the judges Laffavette de Andrada e Gonçaves de Oliveira renounce sequentially to the function of ministers of the FSC. Cfr.: GALLOTTI, Luiz. Discurso do Ministro Luiz Gallotti ao transmitir a presidência do Supremo Tribunal Federal. Diário da Justiça, $16 \mathrm{dez}$, Brasília: Diário Oficial da União, 1968, p. 5365-5366; e: GALLOTTI, Luiz. [Discurso]. In: Sessão Solene do Plenário do Supremo Tribunal Federal, 1., 1969, Brasília, em 5 de fevereiro de 1969: homenagem aos Senhores Ministros Aposentados, Brasília: Diário da Justiça, 1969, at. 285-286.

${ }^{44} \mathrm{It}$ is remote the political mismanagement of forced retirement, blackmail and packing attempts of the FSC judges. See the historical precedents, since 1863, in the narratives of Pedro Calmon, FlávioGalvão, MaurícioLacerda, Rodrigo Lacerda, and de Pires e Albuquerque: CALMON, Pedro. O Rei filósofo: vida de D. Pedro II. Edição ilustrada. São Paulo, Rio de Janeiro, Recife, Porto Alegre: Companhia Editora Nacional, 1938, p. 123-124; LACERDA, Mauricio. História de uma covardia. Rio de Janeiro: Freitas Bastos, 1927; GALVÃO, Flávio. Sebastião de Lacerda, juiz do Supremo Tribunal Federal. Revista do Tribunal de Contas do Município de São Paulo, N ${ }^{\circ}$ 25, Ano VIII, Abril de 1979; LACERDA, Rodrigo. A República das Abelhas. São Paulo: Companhia das Letras, 2013, p. 158-159; PIRES E ALBUQUERQUE, A. Culpa e Castigo de um Magistrado. $3^{\text {a }}$ ed. Rio de Janeiro: Hunos, 1972, at. 128. 
perspective - of the anterior constitutional ordinance, what by convention has been called the "retrospective interpretation" 45 bringing to light the advertence that the most decisive and lasting political legacy of the President of the Republic is their indications to the Supreme Court ${ }^{46}$. In a pioneer study about the decisions of the Brazilian Supreme Court in moments of political instability, between the periods of 1964-1975, Osvaldo Trigueiro do Vale made questionnaire with some of the justices of the Court, some of them compulsorily retired due to an act of force of the regime, coming to the conclusion that in Brazil, in the periods of dictatorship and rupture with the democratic experience the legislative is closed, but "not the courts", although manipulations do occur in respect to the number of judges, with substitutions by justices aligned with the regime, and retirement of those that cause some annoyance, fact also quite documented in the work "The Brazilian Supreme Court Untold History" ${ }^{\prime 4}$. It is a fact relatively little divulged that, in April 1978, the military government intended to transform the Brazilian Supreme Court in a Constitutional Council, "whose political functions would substitute the discretionary action of the revolutionary government", in a political reform project ${ }^{48}$.In a certain sense, if the Court were to keep unshaken the structures of the dictatorial regime, even after its debacle, it would not only assume the face of the regime, but it would also seem to show that it does not have any inconvenience in supporting it. It substitutes the discretionary action of the dictatorship, in a silent, informal, and normative transition ${ }^{49}$. One indicative that the legitimizing rhetoric of some decisions of the Brazilian Supreme Court to the dictatorship of 1964-1985 was what the regime expected from the $\mathrm{FSC}$, as inferred from the changes in its composition throughout history, repetitions of the packing ("Court packing ${ }^{50 "}$, , with 16 judges retired due to acts of force in three distinct moments $(1863,1931$, and, 1968). Based in thesis and juridical arguments, the Brazilian Supreme Court, after the democratic opening and posteriorly in the constitution of 1988, remains approving acts practiced in the dictatorship, as the

${ }^{45}$ SeeBARROSO, Luis Roberto. Interpretação e Aplicação da Constituição. $4^{\mathrm{a}}$ ed., Rio de Janeiro: Saraiva, 2001, p. 71.

${ }^{46}$ According to the letter sent by north-American President Gerald Ford to a friend, revealer of the ambition of perpetuating the presidential legacy through the ministers of the Supreme Court. See TREANOR, William Michael. Lesson for Obama in Ford's selection of Stevens. Disponívelem: <http://law.fordham.edu/17791.htm>, acessoem: 22.10 .2020

${ }^{47}$ See the fruitful analysis of the Brazilian Supreme Court under the presidency of the justices Ribeiro da Costa (1964-1966), the presidency of Justice Luiz Gallotti (19661968), the presidency of JusiticeGonçalves de Oliveira (December 11, 1968 to 18 January 1969), Luiz Gallotti's interim presidency (January to February 1969), Presidency of Justice Oswaldo Trigueiro (1969-1971), Presidency of Justice AliomarBaleeiro (19711973), Presidency of Justice Eloy da Rocha (1973-1975 ), Presidency of Justice DjaciFalcão (1975-1977), Presidency of JusticeThompson Flores (1977-1979), Presidency of Justice AntônioNeder (1979-1981), Presidency of Justice Xavier de Albuquerque (1981-1983), Presidency of Justice Cordeiro Guerra (1983-1985), Presidency of Justice Moreira Alves (1985-1987), and Presidency of Justice Rafael Maye (1987-1989).See SANTOS, Marcelo Paiva dos. A História Não Contada do Supremo Tribunal Federal. Porto Alegre: Safe, 2009, at. 115-361.

${ }^{48}$ See CAVALCANTI, Themístocles. O Supremo Tribunal Federal e a Constituição. In: MARINHO, Josaphat; ROSAS, Roberto (Coord). Sesquicentenário do Supremo Tribunal Federal. Brasília: UnB, 1982. at. 105.

${ }^{49} \mathrm{By}$ the way, it is quite significant the fact that the participation of the Supreme Federal Court in the dictatorship does not receive any important relevance, and does not integrate any of the 6 phases (consisting of 22 stages) commonly caused in the chronology that analyzes the dictatorship and the subsequent democratic transition..See CODATO, Adriano Nervo. Uma história política da transição brasileira: da ditadura militar à democracia. Rev. Sociol. Polit. n. 25, at. 83-106, 2005.

${ }^{50}$ About the packing, some weeks after the begin of Roosevel's second mandate, he send the altered proposal to the composition of the American Supreme Court, under the pretex that the judges were too old to the office, although they did not require retirement. The president intended to appoint a new member to the Court (then composed of 9 judges) so that each judge had more than 70 years, until the maximum of 15 . The measure happened because the Supreme Court, until then, was invalidating the proposals of the New Deal, but with the pressure of the Court's composition change, that did not get to be implemented, the Supreme Court passed to "support" Roosevelt's political plans. It was in the center of the discussion Roosevelt's popularity, and the pressure that the increase in the number of judges in the Supreme Court could permit the "elastecimento (?) of the Constitution", enticing the creation of jobs the improvement of life conditions for the population, hit by the grave north-American financial crisis, for which the New Deal was nothing more than a promise. . Cfr. HODAK, George. FDR Unveils Court-Packing Plan. ABA Journal, Vol. 93, Issue 2, February 2007, pp. 72; e, LEUCHTENBURG, William E. The Origins of Franklin D. Roosevelt's Court-Packing Plan. Supreme Court Review, Vol. 1966, pp. 347-400. . Cfr. HODAK, George. FDR Unveils Court-Packing Plan. ABA Journal, Vol. 93, Issue 2, February 2007, pp. 72; e, LEUCHTENBURG, William E. The Origins of Franklin D. Roosevelt's Court-Packing Plan. Supreme Court Review, Vol. 1966, at. $347-400$. recognizing of impunity of those accused of crimes against humanity during the civil-military regime, especially in the trial of the case of unconstitutionality of the Amnesty Law of 1979 (ADPF 153), or the refusal to cooperate with other neighbor countries to permit the process and trial of those accused of torture and others crimes against humanity committed during the dictatorial regimes, as in the case of Extradition 1362, required by the Argentine State. We highlight that there was not change in composition of the Brazilian Supreme Court in substantive manner, keeping the cabinet of ministers for long years yet, even after the democratic opening; the justices they intended to keep became the substitutes of action of the dictatorial government. Also for the same reason, it seems to have been kept the fidelities they had to the postulates of the previous regime, including the relationship with the "delinquents producing machine"51, gestated during the regime, the election of the enemy included, the notions of the delict, delinquent, delinquency, to the picture of "criminalization processes", inherent to the "delict problem", and the "social control", used as background to achieve the regime's objectives, with doing crimes against humanity ${ }^{52}$.

Time, law and Memory: In recent research, we addressed the relevance of time and memory as hermeneutical devices, also adequate for empirical research ${ }^{53}$. The relations between time and law inspire philosophical discussions and have been assuming a relevant place in contemporary theoretical analysis. One of central thesis in Ost's analysis is that time must be conceived fundamentally as a social institution, and not as a given physical or psychical data. The author invests in what he identifies as frailties in law as a phenomenon that institutes time. Thus, he relates forms of "detemporalization", such as, to mention a few of them, the rejection to the evolutive and finite character of time, described as linear (without fissures). ${ }^{54}$ In the systemic approach time articulates directly to the function of law in relation to the past: stabilization of normative expectations. The determination of individual communications depends on the communicative complex that resorts to time. In other words, it is based on past communications and future potential connections. In this sense, juridical norms configure a set of expectations symbolically generalized. The relation indicates the function of law about the future: an effort to prepare for an uncertain future. ${ }^{55}$ By contemplating time as a relevant unity of analysis, the systemic approach distances itself both from the empty ahistorycism and from the sterile relativism. The focus is oriented to differentiated functional social systems. The historical changes operated in different

\footnotetext{
${ }^{51}$ About that, the reasoning that shall be taken in the sequence of the article, invokes the notion of Jhering's concept of "juridical paradise".

${ }^{52}$ The Argentine case, not less documented, deserves a heading that Carlos Santiago Nino's work (Radical Evil on Trial. New Haven: Yale Univeristy Press, 1996) and the report contained in the publication "Never More, giving account of the massive human rights violation. Equally countless actions were practiced on basis of the law and even on its margin, the crimes against humanity. Despite been marked by his studies in constitutional philosophy and theory of constitution, Nino also deserves to be remembered for his doctorate thesis, before Oxford University - "Los limites de la responsabilidad penal - unateoria liberal del delito" ${ }^{23}$, because in it is funded his argument about the limits and the changes of law to punish. Some works are seminal to reflection about the Argentine Supreme Court, as researched by the professor Andres De Rio Roldan, from the Fluminese Federal University, See DEL RÍO, Andrés. La dictadura argentina en el banquillo: la trayectoria de la justicia y punición a los responsables por los crímenes de lesa humanidad. Política, globalidad y ciudadanía, v. 1, p. 1, 2015; DEL RÍO Andrés. A Corte Suprema de Justiça Argentina e a Ordem Conservadora: UmaAnálise de Trajetórias (1853-1930). Passagens: Revista Internacional de História Política e Cultura Jurídica, v. 1, p. 132-152, 2012; DEL RÍO, Andrés. El desarrollo Institucional de la Corte Suprema de Justicia Nacional y del Supremo Tribunal Federal: Trayectorias comparadas desde el estableciemiento a la democratización. Curitiba: CVR Editora, 2014.

${ }^{53}$ See the discussion about the effects of time in criminal investigation in a research we coordinated about the course of a police investigation in federal justice system: Machado, Bruno Amaral; Zackseski, Cristina; Raupp, Rene Mallet. Tempos da investigação: o transcurso do inquérito policial no sistema de Justiça Federal. Revista Brasileira de Ciências Criminais, São Paulo, ano 24, vol. 124, p. 143-181, out. 2016. In a theoretical approach close to what we suggest in this essay, see, under a sistemic focus, the trials of crimes against humanity and its registers in contemporary critical criminology memory. In: MACHADO, Bruno Amaral: TAQUARY, Eneida Orbage. A tipificação do crime de desaparecimento forçado de pessoas: construção jus internacional e a memória como categoria criminológica crítica. Revista de Estudos Criminais, n. 63, p. 59-94, dez. 2016. ${ }^{54}$ SeeOST, François. O tempo do Direito. Tradução: Elcio Fernandes. Bauru: Edusc, 2005, at. $12-20$.

${ }^{55}$ SeeLUHMANN, Niklas. El derecho de la sociedad.Trad.: Javier Torres Nafarrate. Cidade do México: Herder, 2005, at. 183-187.
} 
social systems generate permanent update of the senses ${ }^{56}$. Memory loses central relevance as psychic and collective category. It is more adequate to talk about social memory, in the form of communications supported on the difference between remembering and forgetting, according to the codes and programs of each functionally differentiated social system ${ }^{57}$. The function of memory is to liberate the capacity of information so that the system opens to new irritations, synthetized in the binary double remembering/ forgetting. Forgetting is not the loss of access to the past but consists in a condition for learning and evolution ${ }^{58}$. The social memory is not that what the communications leaves as trail into the individual consciences, but as the result of the operative communications themselves. Every communication updates a certain sense (reason of the social memory) ${ }^{59}$. The repetitive use of the same references allows us to infer that so shall be it in future cases. In synthesis, if evolution occurs in the form of variation - selection - re-stabilization, the operative memory of the system is concerned with coupling the past to the future, through distinctions ${ }^{60}$. From the recursive mechanism of new autopoietic operations, the observer can identify the structural changes historically updated, or reestablished. Therefore, it is possible to observe the different social semantics. When the focus is directed to the social systems, the senses that events suggest (irritation) to the distinct social systems are privileged $^{61}$.

Semantics of Forgetting: Etymologically, the word "pardon" is constituted by the junction of "per", linked to "perfectly", and "donare", related to give or prevent, used in the sense of "forgiving", and Amnesty, from Greek origin, in a similar sense. The first is used as "guilt remission", and the latter refers to the "removal from memory", Romanian-Germanic system, it means the extinction of the punishability by the effect of time, with the message that certain acts must be forgotten. In the juridical lexicon, it constitutes a message from the State that we are "forgetting" that the perpetrators committed massive and brutal violations of human rights, such as torture, rape, murder ${ }^{63}$. In the sense proposed by CherifBassiouni, such acts of oblivion (impunity) configure a sort of treason to human solidarity with relation to the victims of the conflicts with which we all have the duty of justice, memory and compensation ${ }^{64}$. Carlos $\mathrm{Nino}^{65}$, in an analysis of the radical evil judgment, approaches the central aspect of the theme with an uncomfortable question: How should we answer to the massive violations of human rights, be it by state agents or by other people with the tolerance or consent of their rulers? The answer lies in two positions: when confronted with such atrocities, the governments that succeed the terror regimes should opt to judge and punish the authors of these crimes, or, alternatively, if no measure is taken, they will be left unpunished. The massive violations of human rights are that which Kant considered as "radical evil", in a manner that contemplates not only the atrocities committed during the holocaust, but every and any phatic situation in terms of human rights violation ${ }^{66}$. The reflections of the Argentine jurist recall

${ }^{56}$ See LUHMANN, Niklas. El derecho de la sociedad. Trad: Javier Torres Nafarrate. Cidade do México: Herder, 2005. at. 335-336.

${ }^{57}$ See LUHMANN, Niklas. El derecho de la sociedad. Trad: Javier Torres Nafarrate. Cidade do México: Herder, 2005, at. 461.

${ }^{58}$ See LUHMANN, Niklas. El derecho de la sociedad. Trad: Javier Torres Nafarrate. Cidade do México: Herder, 2005, at. 457-458.

${ }^{59}$ The author asks why society invents the concept of culture to designate its memory. Culture would be nothing more than the memory of society, a kind of filter that allows us to remember / forget. See LUHMANN, Niklas. La sociedad de la sociedad. Trad: Javier Torres Nafarrate. Cidade do México: Herder, 2007, at. 464.

${ }^{60}$ See LUHMANN, N. La sociedad de la sociedad. Trad: Javier Torres Nafarrate. Cidade do México: Herder, 2007, at. 461-464.

${ }^{61}$ See LUHMANN, N. La sociedad de la sociedad. Trad: Javier Torres Nafarrate. Cidade do México: Herder, 2007, at. 438-440.

${ }_{62}^{62}$ See THORNTON. Pardon and Amnesty. Criminal Law Magazine, v. 6, n. 4, July, 1885. ${ }^{63}$ See YOUNG, Gwen K. Amnesty and Accountability. 35 U.C. Davis L. Rev. v. 427, 2002.

${ }^{64}$ See BASSIOUNI M. Cherif. Searching for Peace and Achieving Justice: The Need for Accountability, 59 Law \& contemp. Probs. v. 9, n. 27, 1996.

${ }^{65}$ See NINO, Carlos Santiago. Radical Evil on Trial. New Haven: Yale University Press, 1996 , at xii-xii.

${ }^{66}$ In the words of Carlos Nino: "If someone confronted Adolf Hitler, and told him that his actions were wrong, that would have sounded almost laughable. "Wrong" is a very weak adjective to describe recognized actions that have caused the death of more than 20
Hanna Arendt about the nature of the "Radical Evil", and that we are "incapable of forgiving that which we cannot punish", besides being "incapable of punishing that which has become unforgiveable", because the "radical evil" cannot be punished or forgiven, making such acts transcend the realm of known human affairs ${ }^{67}$. The proposal goes beyond a mere wordplay. It refers to the notion that, for some sorts of crimes, as the ones against humanity, to think in forgiving we must before investigate, prosecute and hold one accountable. Beyond all that, we must remember them so that they will not be once again a viable option. And, especially, not to transform exceptional acts in ordinary ones, by using the known juridical terminology and shared by the jurists.

Oblivion as punshiment (of whom? why?): In another perspective, obiter, we can also observe the oblivion as a form of punishment (penalty), such as Freitas and Zackseski indicated, when discussing about the effect of time in the justifyingcase of the historical revisionism of Wilson Simonal ${ }^{68}$. The effects of the oblivion imposed (or caused), linked to some Hellenic notion of ostracism, would be crueler than one criminal condemnation, because it would be more lasting than the greatest penalty provided in the legislation. As it is known, Wilson Simonal was a successful singer, but had his history abruptly marked by events that linked him as an informer and ally to the military dictatorship, when he stopped being invited to television programs, talk shows, and presentations in musical festivals. The singer's trajectory was narrated in the cinebiography in rescue of his image, denouncing the perverse effects of those accusations that pushed him from stardom to oblivion ${ }^{69}$. The event suggests that we think of forgetting as punishment, because the forgetfulness imposed by amnesty, prescription or pardon is equivalent to penalizing the memory of victims of massive human rights violations, as well as how to prolong its effects for their families.

The oblibion as limit and as Protection (of whom? why?) : On the other side, we can also observe the effects of time, when linked to the normatively determined (and forced) oblivion as limits to punishment. The limits to punishment, evidently, adjust to the criminal political options, but also equal to treating massive violations of human rights as common and ordinary crimes. What would be the minimum fundaments that legitimize equality of treatment between massive violation of human rights and ordinary crimes? This question evidences the protection system of human rights, and the perspective to be adopted by a determined social group. But, above all, it exposes the rhetorical use of the equally principle. Finally, we can reflect about the oblivion as protection. When we take normatively the effects of time as one's protection mechanism, we need to ask: of whom? Why? In the hypothesis of massive violation of human rights, the protection aims to favor, largely, the torturers, rapists, and murderers in mass. This answers the first question, but it makes uncomfortable the approach to the second question. What would be the basis of protecting the authors of such acts? From an initial perspective, we can think of a massage that approves (implicitly) the practice of massive violation of rights, because there is a background equally uncomfortable: punishing such acts would be tantamount to saying the dictatorial regime erred, and leaving them unpunished is equivalent to saying that one agrees with the practiced acts, in which man has become a thing, with ends justifying the means (whatever they were).

millions of people, and the unimaginable suffering of so many millions more". See NINO, Carlos Santiago. Radical Evil on Trial. New Haven: Yale University Press, 1996.

${ }^{67}$ Still with Carlos Nino: "This image of impotence, in the face of radical evil ("mal radical") may initially seem like nothing more than a literary device, as a way of expressing the inadequacy of the evolution of humanity, of human justice, or of our capacity to punish. But more substantially, it means the difficulty of responding to radical evil (radical evil) with ordinary means that are commonly applied to common criminals." See NINO, Carlos Santiago. Radical Evil on Trial. New Haven: Yale University Press, 1996, at. xii.

${ }^{68}$ See ZACKSESKI, Cristina; FREITAS, Felipe da Silva. O esquecimento como pena a partir da trajetória de Wilson Simonal. In: MACHADO, Bruno Amaral; ZACKSESKI, Cristina; DUARTE, Evandro Piza. Criminologia e Cinema: narrativas sobre a violência. São Paulo: Marcial Pons/Fundação Escola Superior do Ministério Público do Distrito Federal e Territórios, 2016

${ }^{69}$ See, for more details, thebiopic (documentary): "Ninguém sabe o duro que dei", 86 minutos, 2009 
From the referred possibilities of readings of the effects of time, as means of extinguishing of the punishability, with the consequent oblivion, let us briefly summarize the cases of ADPF 153 and Extradition 1362, judged by the Brazilian Supreme Court, for a global reflection on the theme.

The adpf 153: when forgiving is a seal of approval: The Federal Council of the Brazilian Bar Association judged, in 2008, the Argumentation of the Non-Compliance Precept before the Brazilian Supreme Court (ADPF 153), postulating the unconstitutionality of provisions of the Amnesty Law (Law n. 6683, from December 19 of 1979), in order to proceed with the "interpretation according to the Constitution", so that it would declared that the amnesty granted to the political crimes or related should not be extended to the common crimes perpetrated by the repression agents against political opponents, during the dictatorial regime (1964-1985). The aim with this, it is certain, was to avoid the extinction of the punishability of the State agents or other ones with the connivance of the Brazilian State who had practiced serious violations of human rights during the dictatorship, as it can be seen from the initial petition, elaborated and subscripted by Fabio KonderKomparato and by MaruíciaGentil Monteiro.

The Brazilian Supreme Court, on April 2010, captained by the vote of minister Eros Grau, by the majority of votes (ministers Carlos Ayres Brito and Ricardo Lewandowski the lost votes and, absent, the minister Joaquim Barbosa, and minister Dias Toffoli, impeded) judged unfounded the demands, on the grounds that it was necessary "not to forget", so that things would not go back to be as they were in the past, concluding the final decision: "I judge thecause unfounded". Certainly, to base the constitutionality of the Amnesty Law on the needof "not forgetting" the acts which it seeks to "erase", refers to Carroll's literary metaphors. When the court approved the juridical act of the dictatorial regime, in 1979, it recognizes the juridical validity of all the acts practiced in exception regime: election of the regime's enemy, definition of the crimes and the criminals. In this sense, we argue that to amnesty is to approve the acts of the exception regime. When the decision seeks contrary fundament to what it should have been ("not to forget" to forget), it is transmitted the encrypted message that the massive violation of human rights, practiced during the regime, can be less relevant than to define if entering the movie theater with popcorn and soda bought outside the establishment wounds the Constitution (ADPF 398), or if the cockfights also violate the Constitution (ADI 1856). Hence, triumphs Lewis Carroll, be it by racing in the same place, by the necessity to ask who bosses to know how much is $2+2$, or by the repetition of the narrative, that becomes true when its simple repetition, also represent rule n. 42: forgetting is not forgetting, and vice-versa.

Extradition n. 1362: when not extraditing is to perpetuate the violation: In the case of the Extradition n 1362, the Argentine State solicited Brazil a the national Argentinian to be sent to the soliciting State to be prosecuted by the practice of crime against humanity, for participating in the terrorist organization triple A (Anticommunist Argentine Alliance), causing the deaths of various people, as well as by his effective participation in the terrorist political project of the Argentine State, during the dictatorship. The proceeding refers to some fragments of the Argentinian history. According to the historical narrative about the political movements that alternated in power in Argentina, considered the most remarkable historical cycles (the first from 1810-1860, the second from 1860-1930, and the, third, from 1930-1983) ${ }^{70}$, Juan Péron was deposed by the military in 1955 , and exiled in Spain, keeping significant influence over politics from Madrid $^{71}$. The military allowed, in a posterior moment, the Peronist party dispute the elections of 1973, although Perón had not obtained legal authorization for such. The elections of that year were won by Hector Cámpora, who eventually renounced after losing the political

\footnotetext{
${ }^{70}$ According to Carlos Nino, during the three Argentine historical cycles, there is a recurrence of 4 factors that help explain the massive violation of human rights in that country: ideological dualism, corporatism, concentration of power and anomie.

${ }^{71}$ See NINO, Carlos Santiago. Radical Evil on Trial. New Haven: Yale University Press, 1996. at. 42 .
}

support ofPerón.A new election was held, culminating in the election of Perón, that came after a few months later, when Isabela, his third wife, assumed the presidential functions, having been known for suffering profound influences of the Welfare minister, José Rega, retired police officer known for creating the terrorist group entitled Anticommunist Argentine Alliance (AAA), group to which the person to extradited belonged. Passing through a profound economic crisis, corruption accusations, and the explosion of violence, the military deposed Isabel Perón from power, on March 1976, when it institutionalized, in the words of Carlos Nino, the most violent authoritarian repressive regime in the history of Argentina. The military board, headed by General Videla, the admiral Emílio Eduardo Massera, and the brigadier Orlando Ramón Agosti, led a wave of unprecedented violence, leading to abduction of those that were contrary to the regime, considered, therefore, as subversives, with acts of torture and murders, and respective concealment of their corpses. Some atrocities were internationally recognized ${ }^{72}$. The terror regime in Argentina accounted for more than 30.000 (thirty thousand) victims, among dead, missing, victims of rape, torture, dead pregnant women, or the kidnapping of their children. A regime of terror that, certainly, imposes us the recognition of the acts practiced in it as crimes against humanity ${ }^{73}$.

Despite this, on November 2016, the Brazilian Supreme Court denied the extradition request, by 6 votes against 5 , under the fundament that it would have happened the prescription of the crimes practiced by the extradited, on the basis of the Foreign Statue (considering the article 77, subsection VI, of the Federal Law n. 6.815/80), that prohibit the extradition in case of extinction of punishability by prescription. Without going further in the fundaments of the votes of SFC justices, what is beyond the scope of this essay, we observe peculiar reference to the oblivion. The Court opted to consider the oblivion as limit and protection of the extradited person, despite the consolidated position of the international organisms, that consider the crimes against humanity imprescriptible. The historiography indicates that the dictatorships of Brazil and Argentina acted together in many cases, under the sign of the Condor Operation. In the ADPF 153, the Brazilian Supreme Court would rather approve (perpetuate), seemingly, the massive violations of human rights than that to protect them. The juridical conception of time, selected by the Court, seems to have been "to forget" to remember ${ }^{74}$. The decisions suggest reflections under the luhmanniana optics. If the function of memory is to liberate the capacity of information to new annoyances, the forgetting presupposes the access to the past: condition for new learning and evolution ${ }^{75}$. Certainly, these were not the messages of the Brazilian Supreme Court in relation to the crimes against humanity submitted to its analysis.

\footnotetext{
${ }^{72}$ According to Carlos Nino's widely documented narrative: "In detention centers, victims were subjected to torture, humiliation, and sexual abuse. The military used techniques such as electric shocks, immersion in cold water, crowding prisoners in cells along with violent dogs. Rape in the presence of relatives of the victims, and with the Jewish victims being placed in a position of humiliation when they were placed in rooms decorated with Nazi swastikas. [...] Jewish detainees were forced to shout "I love Hitler", and had their bodies painted with swastikas." See NINO, Carlos Santiago. Radical Evil on Trial. New Haven: Yale University Press, 1996. at. 55-56.

${ }^{73}$ See MALLIMACI, Fortunato. La Dictadura Argentina: Terrorismo de Estado e Imaginário de la Muerte. Buenos Aires, 2006. Also, note the reports inserted in the documents "Nunca Mas", derived from an Argentine expression to repudiate State terrorism, which occurred during the self-described "National Reorganization Process" regime, and also used frequently by political activists, and whose popularization is due to the fact that it was the name adopted in 1984 by the National Commission on the Disappearance of People (CONADEP) for editing an investigative report on the crimes committed.

${ }^{74}$ Human dignity seems to have many addresses and the Brazilian Supreme Court suggests that we observe it through the lenses of characters literary works, such as those that populate Alice's universe, in "País of Wonders". So we can infer when the Brazilian Supreme Court, when deciding from relatively similar factual assumptions, especially in the case of the extradition of two Argentines requested by the State Argentine, at different times, and that it is now worth remembering. In 1984, when considering the request for Extradition $n^{\circ} 417$, by Mário Eduardo Firmenich, accused of being the author of several crimes, and a member of the Argentine left, leadership of the Montonero movement, the Supreme Court granted extradition, recognizing legitimate the declaration of unconstitutionality of the Argentine Amnesty Law, and therefore accepting the nonextinction of punishment. Check the discussion about the unconstitutionality of the Argentine amnesty law, in the Extradition 417 judgment, especially the vote of the Justice Alfredo Buzaid.

${ }^{75}$ See LUHMANN, Niklas. El derecho de la sociedad. Trad: Javier Torres Nafarrate.
} Cidade do México: Herder, 2005. at. 457-458. 


\section{Conclusion}

The systemic focus allows us to deepen the discussion about the decisions (communications) of the FSC. On one side, when we compare the updated programs of the juridical system, in the form of international human rights treaties and conventions, as well as individual rights and constitutional guarantees, we argue that the analyzed decisions do not adjust to the valid law. The point of observation that we adopt (criminology of the human rights) evidence that the juridical rhetoric constitutes a legitimizing mechanism of selective processes of the penal control organizations (in the case of the FSC). In the definition process of the crime and the criminals, the approval of the acts of crimes against humanity in the dictatorial regimes refers to what Zaffaroni describes as Denialist Criminology ${ }^{76}$. We propose, therefore, that our look, oriented through social memory of the critical criminology, must contemplate discursive strategies to unveil the juridical argumentation that neutralizes and justifies the crimes against humanity (Precautionary Criminology) ${ }^{77}$. We go back to Lola, to observe that, yet, and once again, it persists the triumph of Lewis Carroll. No only by that image of running in the same place, or that to know how much is the $2+2$ sum yet it is required to know the will of that who bosses. "Rule n.42" materializes, whose repetition, as in the Snark hunt, intends to make it true only by the simple fact of repeating it. As they were repeated, and continue to be, the massive violations of human rights provoked by the exception regimes. When the penal control organizations perpetuate the agenda created by the body of extrapenal control, a peculiar form of exception state is eternized. And that soon acquires the uncomfortable status of rule, even if it is the kind coined in the metaphor of "rule n.42". Lola warned us constantly about the triumph of Lewis Carroll. When reality confirms fiction, maybe we are exalted pretenders, lovers of fiction, and deservers of Bentham's critic: "By fanaticism or juridical artifice, one great deal of the juridical ordainment was locked in unintelligible characters and in a foreign language. Fictions, tautologies, technicalities, irregularities

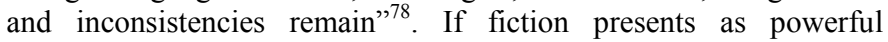
semantic artifact for the juridical hermeneutics, it is because it inspires and instigates us to widen the horizon of our senses in relation to the normativity and the facts. The memory of critical criminology, here represented by the writings of Lola, warns us about the facticity ${ }^{79}$ of the juridical acts funded in a sort of solipsism, indifferent and averse to history, in peculiar from of forgetting, that blocks our access to the past.

\section{REFERENCES}

ALBUQUERQUE, Aluísio Xavier de; ABREU, IdunaWeinert de. Representações por Inconstitucionalidade: Dispositivos de Constituições Estaduais (Tomos I, II e III). Brasília: Subsecretaria de Edições Técnicas do Senado Federal, 1976.

ANITUA, Gabriel Ignacio. Historia de los pensamientos criminológicos. Buenos Aires: Del Puerto, 2005.

BARATTA, Alessandro. Criminología crítica e crítica do direito penal:Introdução à sociologia do direito penal. $2^{\mathrm{a}}$ ed..Trad.: Juarez Cirino dos Santos. Rio de Janeiro: Freitas Bastos, 1999.

BASSIOUNI M. Cherif. Searching for Peace and Achieving Justice: The Need for Accountability, 59 Law \& contemp. Probs. 9, 27 (1996)

\footnotetext{
${ }^{76}$ See ZAFFARONI, Eugenio Raúl. A palavra dos mortos. São Paulo: Saraiva, 2012.

${ }^{77}$ On the social memory of critical criminology and the judgment of crimes against humanity, see MACHADO, Bruno Amaral: TAQUARY, EneidaOrbage. A tipificação do crime de desaparecimento forçado de pessoas: construção jus internacional e a memória como categoria criminológica crítica. Revista de Estudos Criminais, n. 63, p. 59-94, dez. 2016.

${ }^{78}$ See BENTHAM, Jeremy. Constitutional Code, Works. Cidade: Bowring, 1843. p. $77-$ 78; também na versão reimpressa: OGDEN, C.K. Bentham' TheoryofFictions. New York: Kegan Paul, 1932; Também a tradução espanhola: BENTHAM, Jeremy. Teoría de las FiccionesJurídicas. Madrid: Marcial Pons, 2005.

${ }^{79}$ See the analysis on functional imperatives of the economic system and the way in which the positive law can lend legitimacy to illegitimate powers: HABERMAS, Jürgen. Facticidad y validez: sobre el derecho y el Estado democrático de derecho em términos de teoría del discurso. 4. ed. Madrid: Trotta, 2005. at. 103.
}

BEEBEE, Thomas. Can Law-and-Humanities survive Systems Theory? Law \& Literature, n. 244, 2010.

BENTHAM, Jeremy. Constitutional Code, Works, Vol. IX, Bowring, ed., 1843, p. 77-78;

BENTHAM, Jeremy. Teoría de las Ficciones Jurídicas. Madrid: Marcial Pons, 2005.

BERGALLI, Roberto et al. Control Social Punitivo. Sistema penal e instancias de aplicación (Policía, Jurisdicción y Cárcel). Barcelona: Editorial María Jesús Bosch, S.L., 1996.

BERGALLI, Roberto. Argentina: cueestión militar y discurso jurídico del olvido. Doxa, Cuadernos de Filosofía del Derecho, n. 4, 1987, pp. 381-402.

BERGALLI, Roberto. Una sociología del control penal para América Latina: la superación de la criminología. In: BERGALLI, Roberto; BUSTOS RAMÍREZ, Juan (Comp.). El poder penal del Estado. Buenos Aires: Depalma, 1985, p. 3-23.

BLANCHARD, Margaret A. The American Urge To Censor: Freedom of Expression Versus the Desire to Sanitize SocietyFrom Anthony Comstock to 2 Live Crew. $33 \mathrm{Wm}$. \& Mary L. Rev. 741, 1991.

BOHOSLAVSKY, Juan Pablo. ¿Usted también, doctor?: Complicidad de jueces, fiscales y abogados durante la dictadura. Buenos Aires: SigloVeintiuno Editores, 2015

BRASIL. Ato Institucional de 1964, de 9 de abril de 1964. Dispõe sobre a manutenção da Constituição Federal de 1946 e as Constituições Estaduais e respectivas Emendas, com as modificações introduzidas pelo Poder Constituinte originário da revolução Vitoriosa, 1964.

BRASIL. Comissão Nacional da Verdade: Relatório. Brasília: CNV, 2014.

BRASIL. Constituição de 1937, de 10 de novembro de 1937.

BRASIL. Pesquisa Brasil Nunca Mais. São Paulo: Arquidiocese de São Paulo, 1985.

BRASIL. Supremo Tribunal Federal. ADPF n ${ }^{\circ} 153$, rel. min. Eros Grau, 2010.

BRASIL. Supremo Tribunal Federal. ADPF no 320, rel. min. Luiz Fux, 2013.

BRASIL. Supremo Tribunal Federal. Extradição no 1362, Rel. Min. Edson Fachin. Relator para o acórdão, min. Teori Zavascki, 2016.

BRASIL. Supremo Tribunal Federal: 150 anos. Brasília: STF, 1978.

BRENZEL, Jeff. Por que os super-heróis são bons? Os quadrinhos e o anel de Giges. Em: IRWIN, William (Coord.). Super-Heróis e a Filosofia. Verdade, Justiça e o Caminho Socrático. São Paulo: Madras, 2009.

CALMON, Pedro. O Rei filósofo: vida de D. Pedro II. Edição ilustrada. São Paulo, Rio de Janeiro, Recife, Porto Alegre: Companhia Editora Nacional, 1938.

CARROLL, Lewis. Alice no País das Maravilhas. Trad. Clélia Regina Ramos. São Paulo: Universo dos Livros. 2014.

CARROLL, Lewis. The Hunting of the Snark. LightningSource, 2007.

CAVALCANTI, Themístocles. O Supremo Tribunal Federal e a Constituição. Em: MARINHO, Josaphat; ROSAS, Roberto (Coord). Sesquicentenário do Supremo Tribunal Federal. Brasília: Editora UnB, 1982.

CHAVES JUNIOR, Airto. Além das Grades: a paralaxe da violência nas prisões brasileiras. Florianópolis/SC: TirantloBlach, 2018.

CODATO, Adriano Nervo. Uma história política da transição brasileira: da ditadura militar à democracia. Rev. Sociol. Polit. n.25, 2005.

CORN-REVERE, Robert. Moral Panics, the First Amendment, and the Limits of Social Science. 28Comm. Law, 4, 2011.

CORREA S, Jorge. Dealing with Past Human Rights Violations: The Chilean Case After Dictatorship. Notre Dame Law Review, vol. 67, 1992.

DE CASTRO, Lola Aniyar. Criminologia da Libertação. Rio de Janeiro: Revan, 2005.

DE CASTRO, Lola Aniyar. La Criminologia Crítica em Siglo XXI como criminologia de losderechos humanos y contra-reforma humanística o las teorias criminológicas no son inocentes. Em: Revista Interferencia - Derechos y seguridade humana, 2009. 
DE CASTRO, Lola Aniyar. O triunfo de Lewis Carroll. Em: A nova criminologia latino-americana. Discursos sediciosos: crime, direito e sociedade. Rio de Janeiro: Freitas Bastos, 2000.

DE CASTRO, Lola Aniyar. Pensamento Criminológico. Da Criminologia Clássica à Criminologia dos Direitos Humanos. Belo Horizonte: Mandamentos, 2004.

DE CASTRO, Lola Anyiar. El Jardín de al lado. Revista Doctrina Penal, Depalma, n. 8, Buenos Aires, 1985

DE CASTRO, Lola Anyiar. Un debate sin punto final. Revista Doctrina Penal, Depalma, n. 11, Buenos Aires, 1988.

DE MELLO, Thiago. Entrevista: Autor de 'Faz Escuro Mas Eu Canto', Thiago de Mello comemora 90 anos em São Paulo. Estadão. Caderno Cultura, de 15 de março de 2016. Disponível em: $\quad<$ http://cultura.estadao.com.br/noticias/literatura,autor-defaz-escuro-mas-eu-canto--thiago-de-mello-comemora-90-anosem-sao-paulo,10000021236>, acesso em: 21.11.2016

DE MELLO, Thiago. Faz Escuro, mas eu canto. $21^{\text {a }}$ Ed. São Paulo: Bertrand Brasil, 2003.

DEL RÍO, Andrés. A Corte Suprema de Justiça Argentina e a Ordem Conservadora: UmaAnálise de Trajetórias (1853-1930). Passagens: Revista Internacional de História Política e Cultura Jurídica, v. 1, p. 132-152, 2012.

DEL RÍO, Andrés. El desarrollo Institucional de la Corte Suprema de Justicia Nacional y del Supremo Tribunal Federal: Trayectorias comparadas desde el estableciemiento a la democratización. Curitiba: CVR Editora, 2014.

DEL RÍO, Andrés. La dictadura argentina en el banquillo: la trayectoria de la justicia y punición a los responsables por los crímenes de lesa humanidad. Política, globalidad y ciudadanía, v. 1, p. 1, 2015.

DO VALE, Osvaldo Trigueiro. O Supremo Tribunal Federal e a instabilidade politico institucional. Dissertação de Mestrado. Escola de Administração Pública da FGV. Rio de Janeiro, 1975.

DREYFUSS, René Armand. 1964: A Conquista do Estado. Ação Política, Poder e Golpe de Classe. Trad. Laboratório de Tradução da Faculdade de Letras da UFMG. $5^{\text {a }}$ Ed. Petrópolis: 1987.

DUSSICH, John P. J. Violence And The Media. Criminology 80, 1970; PETTY, Ross D. The 'Amazing Adventures' of Super Hero. 100Trademark Rep. 729, 2010.

FENNELL, Jack. The aesthetics of Supervillainy. 16Law Text Culture, vol. i 2012.

FERGUSON, Robert. Inferno: An Anatomy of American Punishment. New Haven: Harvard University Press, 2014.

FISS, Owen. The Death of a Public Intelectual. The Yale Law Journal, vol. 104, 1995.

FRIEDMAN, Barry. The Will of the people: how public opinion has influenced the Supreme Court and shaped the Constitution. New York: FSG, 2009.

GALLOTTI, Luiz. [Discurso] Ao transmitir a presidência do Supremo Tribunal Federal. Diário da Justiça, 16 dez, Brasília: Diário Oficial da União, 1968, p. 5365-5366.

GALLOTTI, Luiz. [Discurso]. In: Sessão Solene do Plenário do Supremo Tribunal Federal, 1., 1969, Brasília, em 5 de fevereiro de 1969: homenagem aos Senhores Ministros Aposentados, Brasília: Diário da Justiça, 1969, p. 285-286.

GALVÃO, Flávio. Sebastião de Lacerda, juiz do Supremo Tribunal Federal. Revista do Tribunal de Contas do Município de São Paulo, No 25, Ano VIII, Abril de 1979.

GREENBERG, Marc H. Comics, Courts \& Controversy: A Case Study of the Comic Book Legal Defense Fund. 32Loy. L.A. Ent. L. Rev. 121. 2011.

GUEMBE, Maria Jose. Reopening of Trials for Crimes Committed by the Argentine Military Dictatorship. SUR - Int'l J. on Hum Rts. 115, 2005.

HABERMAS, Jürgen. Facticidad y validez: sobre el derecho y el Estado democrático de derecho em términos de teoría del discurso. 4. Ed. Madrid: Trotta, 2005.

HERRERA FLORES, Joaquín. La Reinvencion de los derechos humanos. Andalucía: ColecíonEnsayando, 2008.

HODAK, George. FDR Unveils Court-Packing Plan. ABA Journal, Vol. 93, Issue 2, February 2007.
LACERDA, Mauricio. Historia de uma covardia. Rio de Janeiro: Freitas Bastos, 1927.

LARRAURI, E. La Herencia de la Criminología Crítica. $3^{\mathrm{a}}$ Ed. Madri: Siglo Veintiuno de España Editores, 2000.

LEUCHTENBURG, William E. The Origins of Franklin D. Roosevelt's Court-Packing Plan. SupremeCourtReview, Vol. 1966.

LINS E SILVA, Evandro. O Salão dos passos perdidos: Depoimento ao CPDOC. Rio de Janeiro: Nova Fronteira e FGV, 1997.

LUHMANN, N. La sociedad de la sociedad. Trad.:Javier Torres Nafarrate. Cidade do México: Herder, 2007.

LUHMANN, Niklas. El derecho de lasociedad.Trad.: Javier Torres Nafarrate. Cidade do México: Herder, 2005.

MACHADO, Bruno Amaral. Discursos criminológicos sobre o crime e o direito penal: comunicação e diferenciação funcional. Revista de Estudos Criminais, $\mathrm{n}^{0}$ 45, abril-junho, 2012, p. 77116.

MACHADO, Bruno Amaral: TAQUARY, Eneida Orbage. A tipificação do crime de desaparecimento forçado de pessoas: construção jus internacional e a memória como categoria criminológica crítica. Revista de Estudos Criminais, n. 63, p. 5994, dez. 2016.

MACHADO, Bruno Amaral; ZACKSESKI, Cristina; PIZA, Evandro C. Cinema e Criminologia: narrativas sobre a violência. São Paulo: Marcial Pons, 2016.

MACHADO, Bruno Amaral; ZACKSESKI, Cristina; RAUPP, Rene Mallet. Tempos da investigação: o transcurso do inquérito policial no sistema de Justiça Federal. Revista Brasileira de Ciências Criminais, São Paulo, ano 24, vol. 124, p. 143-181, out. 2016.

MALLIMACI, Fortunato. La Dictadura Argentina: Terrorismo de Estado e Imaginário de laMuerte. Buenos Aires, 2006.

MAYER, Rafael. Entrevista: História Oral do Supremo [1988-2013]. Rio de Janeiro: Escola de Direito da FGV, 2015.

MELOSSI, Dario. El estado del ccmtrol social. Un estudio sociológico de los cOnceptos de estado y de control social en la conformación de la democracia. México, Siglo XXI, 1992.

MEZAROBBA, Glenda. Between Reparations, Half Truths And Impunity: The Difficult Break With The Legacy Of The Dictatorship In Brazil. SUR - UR - Int'1 J. on Hum Rts. v. 7, n. 13, dec. 2010.

MIGNONET, Emilio Fermin; ESTLUNDTT, Cynthia L.; ISSACHAROFFTTT, Samuel. Dictatorship on Trial: Prosecution of Human Rights Violations in Argentina. 10Yale J. Int'l L. 118, 1984.

MILLS, C. Wright. The Power Elite. Cambridge: Oxford UniversityPress, 1999.

NINO, Carlos Santiago. Juicio al mal absoluto: ¿Hasta dónde debe llegar la justicia retroactiva en casos de violaciones masivas de los derechos humanos? Buenos Aires: Siglo Veintiuno, 2015

NINO, Carlos Santiago. La huida frente a las penas. No hay derecho, II, 4, 1991 .

NINO, Carlos Santiago. Los Limites de la Responsabilidad Penal: Una teoría liberal del delito. Editorial Astrea: Buenos Aires, 1980 .

NINO, Carlos Santiago. Radical Evilon Trial. New Haven: Yale University Press, 1996.

NINO, Carlos Santiago. Se acabó el debate. No hay derecho, III, 8, 1993.

NOVA MONREAL, Eduardo. Desorientación epistemológica en la criminología crítica? Revista Doctrina Penal, n. 8, Depalma, Buenos Aires, 1985.

NOVA MONREAL, Eduardo. Lo que hay al lado no es un jardín: mi réplica a Lola Aniyar de Castro, Revista Doctrina Penal, n. 9, Depalma, Buenos Aires, 1986.

OGDEN, C.K. Bentham' Theory of Fictions. New York: Kegan Paul, 1932.

OST, François. O tempo do Direito. Tradução: Elcio Fernandes. Bauru: Edusc, 2005.

PIRES E ALBUQUERQUE, A. Culpa e Castigo de um Magistrado. $3^{\mathrm{a}}$ ed. Rio de Janeiro: Hunos, 1972. 
PISARELLO, Gerardo. Un largo Termidor: historia y crítica del constitucionalismo antidemocrático. Quito: Corte Constitucional para el Período de Transición, 2012.

POSNER, Richard A. RemarksonLaw and Literature. Loyola UniversityLawJournal, 23, p. 181-195, 1991-1992.

REIBMAN, James E. Ralph Ellison, Fredric Wertham, M.D., And The Lafargue Clinic: Civil Rights And Psychiatric Services In Harlem. 26Okla. City U. L. Rev. 1041, 2001.

REQUA, Marny. A Human Rights Triumph? Dictatorship-era Crimes and the Chilean Supreme Court. HumanRights Law Review $12: 1,2012$

REZEK, Francisco. Entrevista: História Oral do Supremo [19882013]. Rio de Janeiro: Escola de Direito da FGV, 2015.

RIVERA, Tânia. Arte e psicanálise. Rio de Janeiro: Jorge Zahar, 2002.

ROJAS, Gerardo Bernales. La Imprescriptibilidad de la Acción Penal en Procesos por Violaciones a los Derechos Humanos. RevistaIuset Praxis, 13 (1): 245 - 265, 2007.

SANTOS, Marcelo Paiva dos. A História Não Contada do Supremo Tribunal Federal. Porto Alegre: Safe, 2009.

SEÑA, Jorge F. Malem. Carlos Santiago Nino: A Biobibliographical Sketch. Interamerican Law Review, vol. 27, n. 1, 1995.

SILVA, José Afonso da. O Constitucionalismo Brasileiro: Evolução Institucional. São Paulo: Malheiros, 2011.

SIMON, Paul; GARFUNKEL, Art. The Sounds of Silence. Sounds of Silence. Washington: Columbia, 1965.

SOITMAN, Daniel. Applauding Uruguay's Quest for Justice: Dictatorship, Amnesty, and Repeal of Uruguay Law no. 15.848. Washington University Global Studies Law Review, vol. 12, 2013.

THORNTON. Pardon and Amnesty. Criminal Law Magazine, vol. VI, n ${ }^{\circ} 4$, july, 1885.
TREANOR, William Michael. Lesson for Obama in Ford's selection of Stevens. Disponível em: <http://law.fordham.edu/ 17791.htm>, acesso em: 22.11.2016.

TRINDADE, André Karam; GUBERT, Roberta Magalhães; COPETTI NETO, Alfredo. Direito \& Literatura: Discurso, Imaginário e Normatividade. Porto Alegre: Nuria Fabris, 2010;WERTHAM, Fredric. Seduction of the Innocent. $2^{\mathrm{a}}$ Ed. New York: Rinehart \& Co, Inc., 1954.

VAN SWAANINGEN, René. Critical Criminology: Visions from Europe. London: Sage, 1997,

VON JHERING, R En el cielo de los conceptos jurídicos. Una fantasia. em: R. VON JHERING, Bromas y Veras en la jurisprudencia. Trad.: Tomás A. Banzhaf. Buenos Aires: EJEA, 1974.

VON JHERING, R. In The Heaven for Legal Concepts: A Fantasy, Trad. Charlotte L. Levy. Temple Law Quarterly, vol. 58, 1985.

WILLIAMS, Sidney; MADAN, Falconer. Handbook of the Literature of the Rev. C. L. Dodgson, citadosen Martin Gardner: The Annotated Snark, Penguin Books, 1974.

YOUNG, Gwen K. Amnesty and Accountability. 35U.C. Davis L. Rev. 427, 2002

ZACKSESKI, Cristina; FREITAS, Felipe da Silva. O esquecimento como pena a partir da trajetória de Wilson Simonal. Em: MACHADO, Bruno Amaral; ZACKSESKI, Cristina; DUARTE, Evandro Piza. Criminologia e Cinema: narrativas sobre a violência. São Paulo: Marcial Pons/Fundação Escola Superior do Ministério Público do Distrito Federal e Territórios, 2016.

ZAFFARONI, Eugenio Raúl. ¿Vale la pena? No hay derecho, II, 5, 1992.

ZAFFARONI, Eugenio Raúl. A palavra dos mortos. São Paulo: Saraiva, 2012.

ZAFFARONI, Eugenio Raul. BATISTA, Nilo. SLOKAR, Alejandro. ALAGIA, Alejandro. Direito Penal Brasileiro: Teoria Geral do Direito Penal. Rio de Janeiro: Revan, 2003. 